\title{
Regulatory Framework of Mineral Resources Sector in Pakistan and Investment Proposal to Chinese Companies in Pakistan
}

\author{
Muhammad Tayyab Sohail $^{1 *}$, Delin Huang ${ }^{1}$, Earl Bailey ${ }^{2}$, Malik Muhammad Akhtar ${ }^{3}$, \\ Muhammad Afnan Talib ${ }^{3}$ \\ ${ }^{1}$ School of Public Administration, China University of Geosciences, Wuhan, China; ${ }^{2}$ School of Resources China, University of Geo- \\ sciences, Wuhan, China; ${ }^{3}$ Schools of Environmental Studies, Institute of Geophysics \& Geomatics, China University of Geosciences, \\ Wuhan, China. \\ Email: "tayyabsohail@yahoo.com, dlhuang1030@163.com, earlplanner@hotmail.com,malikma_2012@yahoo.com
}

Received ***************2013

Copyright (C) 2013 Muhammad Tayyab Sohail et al. This is an open access article distributed under the Creative Commons Attribution License, which permits unrestricted use, distribution, and reproduction in any medium, provided the original work is properly cited.

\begin{abstract}
This paper presents a scenario for mineral resources and development in this sector in Pakistan. Moreover it mainly comprises of the policies regarding the location of minerals, their extraction, and at the end there are some important suggestions for the Chinese companies as far as the investment point of view is concerned. Regardless of Pakistan's two successive mineral policies and abundant mineral resources, this sector's contribution to overall GDP of country is not sufficient. The reasons may be; inadequate monitoring and evaluation, lack of community base resources management programs, insufficient tax compliance, political instability, weather related problems, insecurity within mineral rich areas and lack of foreign investment in the country. However, there is still room for improved technical and economic analysis of the sector as well as tremendous opportunities for Joint Venture Agreement with other emerging economies and international private partners. China has its own importance and reorganization in the world due to its economic growth and production. Pakistan and China both countries have very good relation from the beginning. Both countries help each other, if there is any need of help. There is still time to realize the national development benefits from the sector.
\end{abstract}

Keywords: China; Minerals Resources; Pakistan; Policy; Industry; Company

\section{Introduction}

Being an agricultural country, around $68 \%$ population of Pakistan is concerned directly or indirectly to agriculture. Moreover Pakistan is also rich in natural resources. But it's very miserable that this sector in Pakistan contributes less than one percent to the national GDP at the end of fiscal year 2011/2012 [1]. It is a very minute contribution given to the total GDP instead of having an immense quantity of mineral resources. This contribution to the total GDP can be increased to $10 \%-20 \%$ in the next ten years which would be influential for the socioeconomic development in the country.

In 1995, government of Pakistan formulated through a broad-based stakeholder's consultation process, and launched the National Mineral Policy (NMP-1) [2]. The

${ }^{*}$ Corresponding author. policy was aimed to enhance the investment and operational environment of the mining sector to attract local and foreign direct investments (FDIs). The revised NMP of 2012 (NMP-2) is geared at identifying and learning from the challenges of the first plan by focusing on five thematic areas: 1) increasing contribution to GDP; 2) international competitiveness and partnership; 3) coordination between state and provincial institutions; 4) sustainable development; and 5) Encouraging small scale local mining. After two sector policies and various changes to the manner in which the industry operates, there seems to be no positive turn around in the sector, let alone any indication that its future is on a path of sustainability. Apart from the minimal contribution to GDP, the sector is also plagued by issues relating to local and ethnic conflicts, which continue to be a hurdle to disrupt operations and ward off potential investors as well as 
problems associated with natural hazards inter alia. The government of Pakistan is now at a crossroads, where the industry is concerned. Pakistani government ought to take bold and innovative changes which are needed for the development and better management in the sector of mineral resources. This should be followed by an identification of the flaws and strengths in this environment and relevant recommendations for the future. Accordingly, attention is brought to the institutional framework and the policy environment that impacts the development and operation of the mineral sector.

\section{Physical Geography of Pakistan}

Pakistan has a landmass of $796,096 \mathrm{~km}^{2}$, making it the eights largest countries in Asia, and a population of over 187 million with a growth rate of 1.6\%/annum [3] making it the sixth most populous country in the world. Located at the crossroads of the strategically important regions of South Asia, Central Asia and Western Asia, Pakistan has a 1046-kilometre (650 mi) coastline along the Arabian Sea and the Gulf of Oman in the south and is bordered by India to the east, Afghanistan to the west and north, Iran to the southwest and China in the far northeast (Figure 1) and the geographical mapping location of Pakistan by the geology survey of Pakistan.

\section{Physical Geography of China}

It is the world's most populous country and second largest country after Russia, with a population of over 1.35 billion. The People Republic of China (PRC) is a single-party state governed by the Communist, with its seat of government in the capital city of Beijing. It exercises jurisdiction over 22 provinces, five autonomous regions, four direct controlled municipalities (Beijing, Tianjin, Shanghai, and Chongqing), and two mostly self-governing special administrative regions (Hong Kong and Macau). The PRC also claims Taiwan which is controlled by the Republic of China (Figure 1). China shares its border with fourteen countries. Being the world's largest economy Chinese companies invest in all over the world in the field of information technology, minerals resources, unconventional energy production sources, agriculture, electronics industry etc. Chinese investors and companies are in heavy collaboration with different countries in different fields for example Pakistan, India, Arab states and in African countries. Being a neighbor of Pakistan, different Chinese companies like cellular, exploration, and construction companies are having a great setup in Pakistan.

\section{Mineral Resources in Pakistan}

Pakistan can be assumed to be a heaven for mineral resources. Several minerals deposit including coal, copper, gold, chromite, salt, bauxite and others (Figures 2 to 5 and Table 1). A variety of precious and semi-precious minerals are also mined, these include peridot, aquamarine, topaz, ruby, emerald, rare-earth minerals bastnaesite and xenotime, sphene, tourmaline (Figures 2-5), and many varieties and types of quartz [4] The mineral industry has grown since independence from exploring only 5 minerals to the current 52 . Since independence, majority of minerals mined were discovered by the Geological Survey of Pakistan (GSP) [5]. Among the ap-

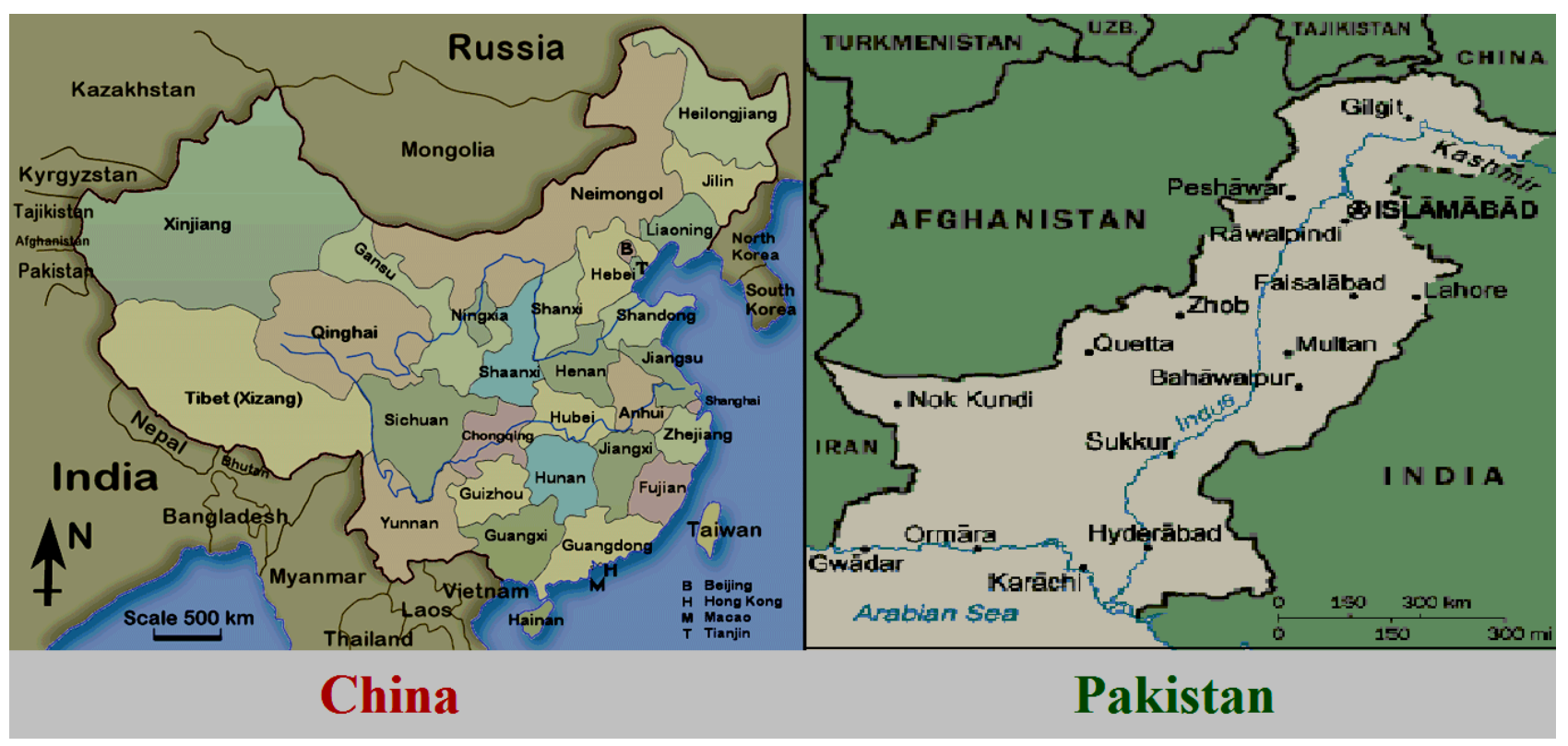

Figure 1. Political map of Pakistan and China and international location. 


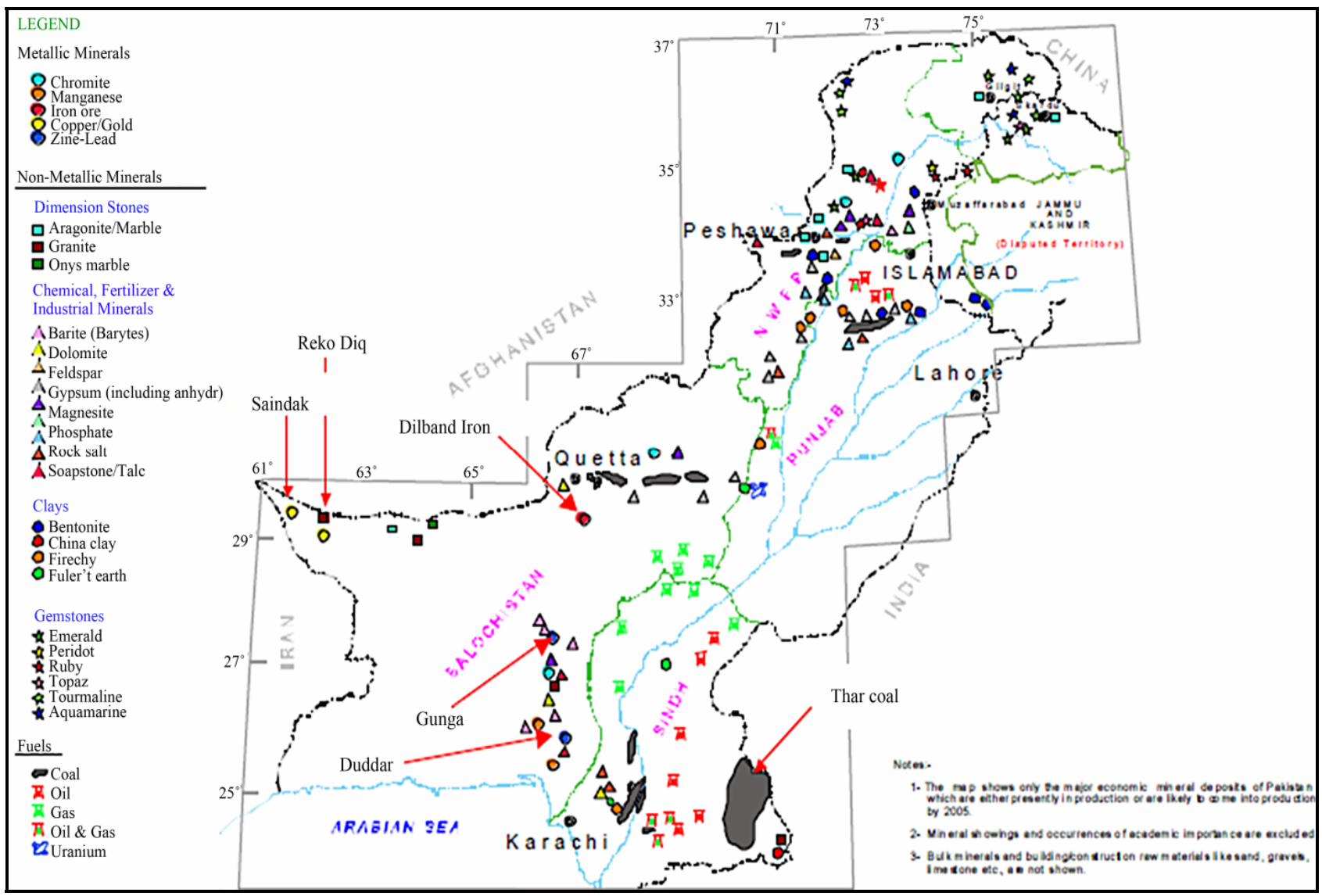

Figure 2. Major mineral resources of Pakistan (Source: Geological Survey Pakistan, 2003).

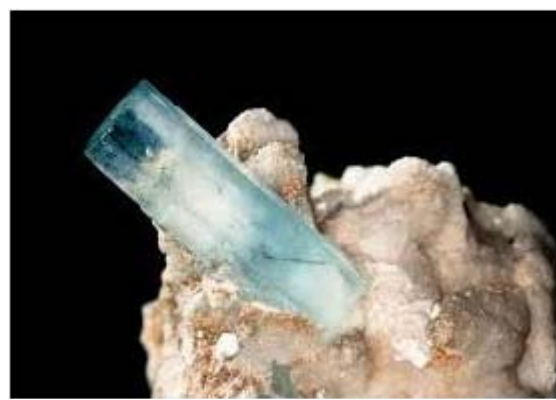

Aquamarine

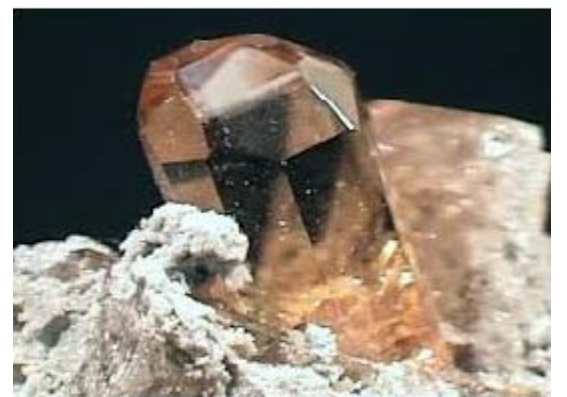

Topaz

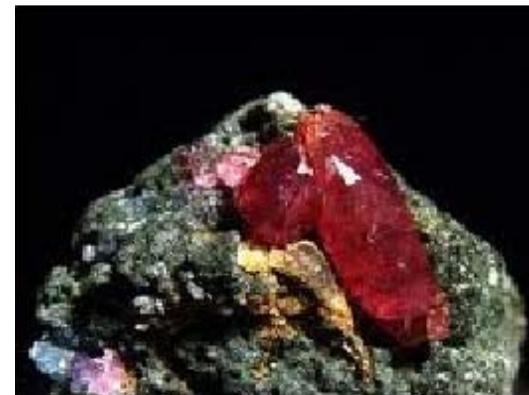

Ruby
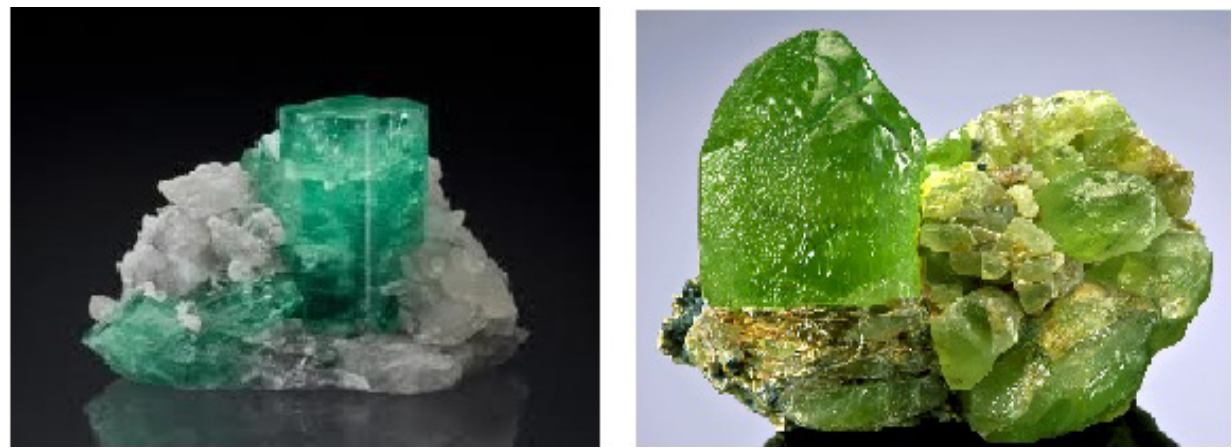

Emerald Perido

Figure 3. Important gemstones in Pakistan. 


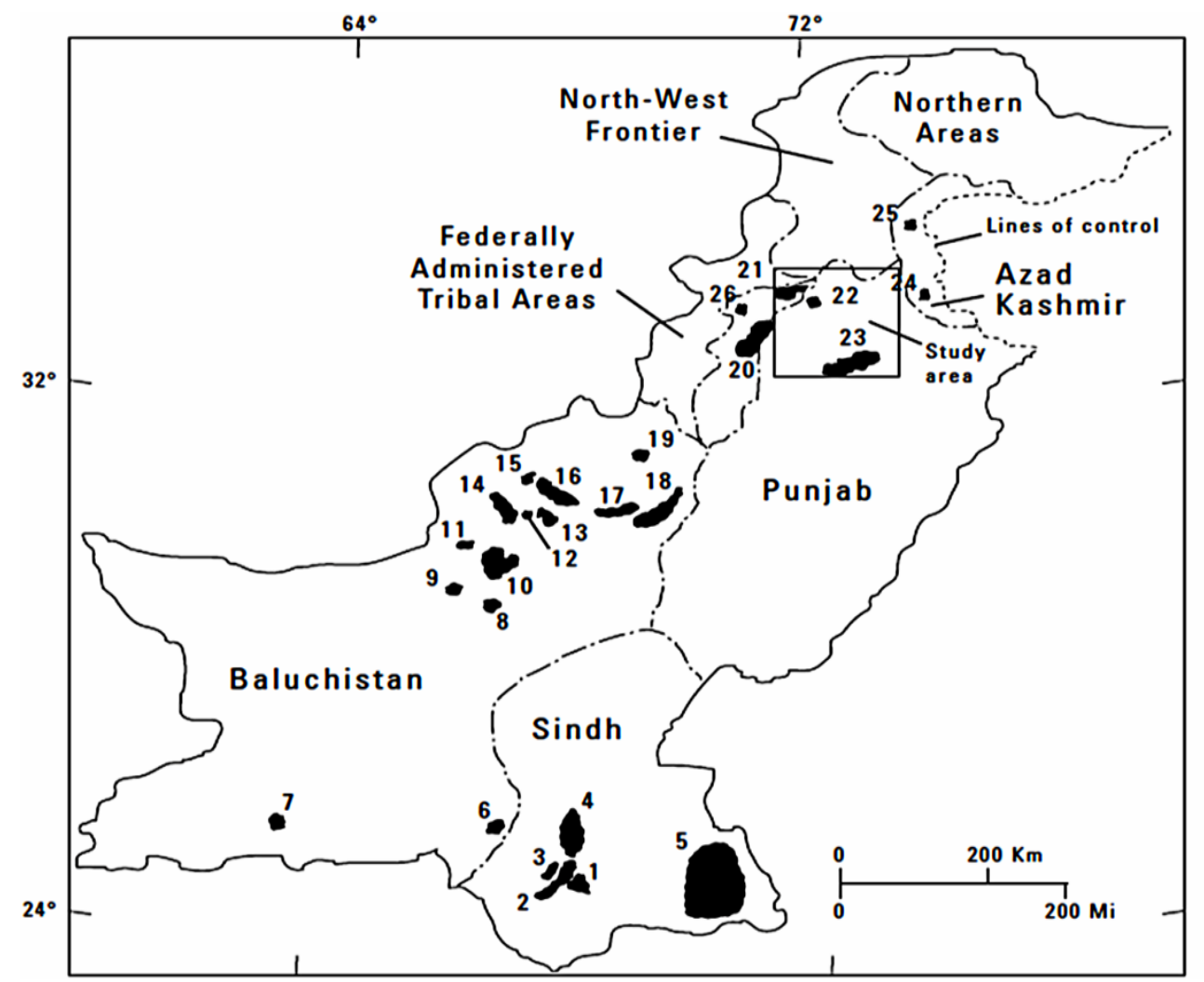

\author{
Coal fields \\ 1 Sonda East \\ 2 Sonda West \\ 3 Meting-Jhimpir \\ 4 Lakhra \\ 5 Thar \\ 6 Dureji \\ 7 Balgor \\ 8 Sanni \\ 9 Johan \\ 10 Mach-Ab E Gum \\ 11 Abi Gul \\ 12 Margat \\ 13 Pir Ismail Ziarat \\ 14 Sor Range-Daghari \\ $15 \mathrm{Kach}$ \\ 16 Khost-Sharig-Harnai \\ 17 Duki \\ 18 Chamalong \\ 19 Badinzai \\ 20 Makarwal-Kurd-Sho \\ 21 Cherat \\ 22 Choi \\ 23 Salt Range \\ 24 Kotli \\ 25 Khilla Muzaffarabad \\ 26 Hangu
}

Figure 4. Distribution of Coal mines in Pakistan (adapted from Warwick and Wardlaw, 2003).

proximately 200 mineral rich countries in the world; Pakistan has the second largest salt mines and coal reserves, fifth largest copper and gold reserves and world's second largest coal deposits of 185 billion tons. It has more than 436.2 million to 618 billion barrels of crude oil and 31.3 TCF of proven gas reserves. The current oil production is 65,997 barrels/day while gas production is $4 \mathrm{BCF} /$ day. Additionally, there is resource.

Potential of 27 billion Barrels of Oil and 282 TCF of gas reserves which has not been explored due to lack of vision and flawed policies [6]. Baluchistan is the richest mineral resources province in Pakistan, but majority of coal deposits are in Thar (Sindh province) (Figure 3). Out of the fifty two minerals in the country, twenty are from the Balochistan region (Table 1). Khyber Pakhtoonkhwa is rich in gems. Apart from oil, gas and some mineral used for nuclear energy production, which comes directly under federal control mines, other mineral deposits are controlled by the Provincial government. Currently, approximately 52 minerals are mined and processed in Pakistan [7]. Coal is found in very large quantities in Thar, Chamalang, Quetta and other sites.

The Khewra Salt Mines, world's $2^{\text {nd }}$ largest mine producing $\sim 220$ million tonnes of rock salt deposits. The current production from the mine is 325,000 tons of salt per annum. In Reko Diq, Baluchistan, deposits of copper and gold are present (Table 1). There are also copper deposits in Daht-e-Kuhn, Nokundi, and in the Chaghi district. Iron ore is found in various regions of Pakistan including Nokundi, Chaniot, Harripur and other Northern Areas.

Also in Kalabagh (less than $42 \%$ quality) where the largest deposits are found. The Eastern shield slope zone has considerable amount of limestone, gypsum, rock salt dolomite, glass sand, celestial, coals, Cis-Indus salt range and newly explored huge reserve in Sindh, which are being utilized for energy generation. Similarly, moderate quantities of gold and copper are found in Chagai, in the Island Arc area where the Geological Survey of Pakistan (GSP) has identified at least 12 porphyry type deposits containing appreciable quantities of gold along with copper and silver [8].

One of the areas of significant mineral deposits is the Federally Administered Tribal Areas (FATA). This is a semi-autonomous tribal region in the northwest of present day Pakistan, laying between Afghanistan to the west and north, and the provinces of Khyber Pakhtunkhwa and Balochistan to the east and south, respectively. The FATA comprises seven agencies tribal districts and six frontier regions. The territory is almost exclusively inhabited by Pashtun tribes, who also live in the neighboring Khyber Pakhtunkhwa and Afghanistan. The territory 


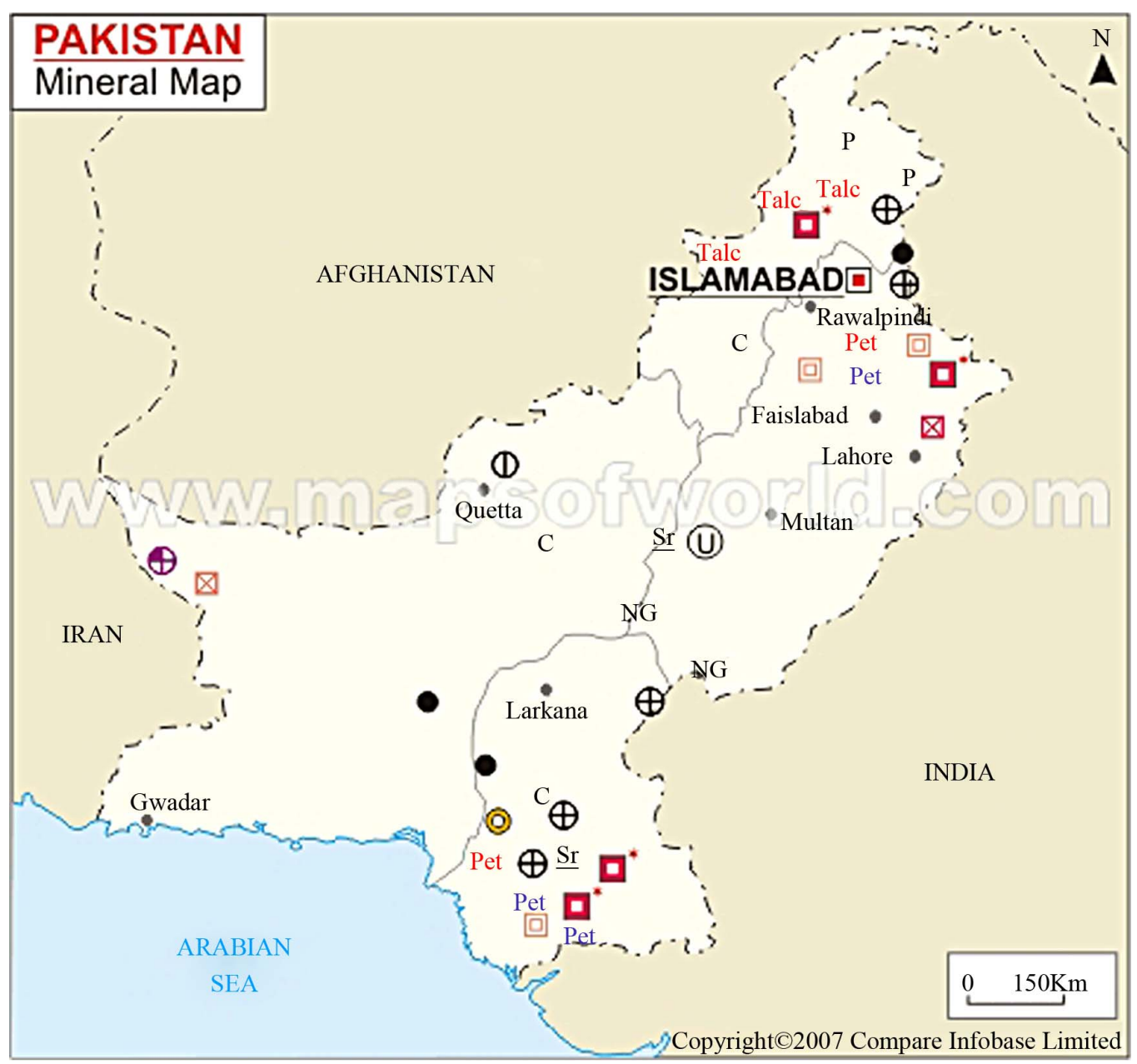

Figure 5. Map of distribution of major minerals in Pakistan (the map shows location of Pet: Petroleum, U: Uranium, NG: Natural Gas, Sr.: Strontium and Talc-Mineral-composed of hydrate and magnesium silicate) source Compare Info base limited, 2007.

Table 1. Estimated recoverable quantities of metals and values in Baluchistan (Source: 2009 GSP and MOPNR).

\begin{tabular}{cccc}
\hline Minerals & $\begin{array}{c}\text { Quantity } \\
\text { (Million tons) }\end{array}$ & $\begin{array}{c}\text { Current Price } \\
\text { (US\$) }\end{array}$ & $\begin{array}{c}\text { Value } \\
\text { (Million US\$) }\end{array}$ \\
\hline Copper & 1.69 & $2000 /$ tones & 3380.00 \\
Gold & 2.24 & $387 / \mathrm{oz}$ & 867.00 \\
Silver & 2.49 & $5.0 / \mathrm{oz}$ & 12.45 \\
\hline
\end{tabular}

is governed through the Frontier Crimes Regulations. Over the last decade there has been moderate increase in mineral production in FATA, with an average $35 \%$ annually since 2004 [9]. This equated to revenue of approximately Rs.31.5 million or USD 3.2 million. Simultaneously, mineral production within FATA during that same period grew by almost $219 \%$. To date nineteen different minerals deposits, including copper, manganese, chromite, iron ore, lead, barite, soapstone, coal, gypsum, limestone, marble, dolomite, feldspar, quartz, silica sand, bentonite, marl, emerald and graphite have been identified in tribal areas within the FATA region, which are still to be exploited. Limestone, chromite and quartz are also in large quantities eastern, as well as small quantities of coal with annual production of 5,705,190 tons in 2004-2005. However these have a low market value both locally and internationally. So far no copper has been extracted in FATA but large deposits exist in North and South Waziristan agencies. For instance, in the Shinkai area of North Waziristan an estimated 27 million tons of copper reserves exist. Unfortunately, the proposed plan of copper enrichment in FATA and establishment of a prototype plant at Shinkai are still to materialize. Table 2 shows a summary of some copper, gold and silver deposits and reserves in Pakistan.

There is no doubt that Pakistan has a wide variety and distribution of minerals. This fact alone supports the formulation of an effective mineral policy and relevant supporting plan for its implementation. The sector is a criti- 
and Investment Proposal to Chinese Companies in Pakistan

Table 2. Proportional policy concerns of NMP-2 and NMP-1.

\begin{tabular}{|c|c|}
\hline NMP-1 & NMP-2 \\
\hline Expansion of employment opportunities and enhancement of skills & Economic development \\
\hline Sustained development of mineral bearing area & $\begin{array}{l}\text { R\&D enhancement, human resource development, as well as promotion } \\
\text { and marketing }\end{array}$ \\
\hline Expanded business opportunities for local industries & Competitiveness and Investment \\
\hline Increased revenue flow to the Provincial and Federal Governments & Effective Governance and management \\
\hline Technology transfer & Environmental Sustainability \\
\hline $\begin{array}{l}\text { Regional infrastructure development and an improved data base of } \\
\text { Pakistan's mineral resources }\end{array}$ & Encourage small scale mining and local private participation \\
\hline
\end{tabular}

cal feature in the ongoing industrialization and economic development process of the country. The GSP calculated the percentage distribution of coal use in Pakistan per industry to be $23.1 \%$ Coke manufacturing, $65.4 \%$ Brick Kiln production and the remaining $11.5 \%$ to power generation. Similarly, percentage share of fuel in commercial energy composition is distributed as $1 \%$ nuclear, $30 \%$ oil, $11 \%$ Coal, $17 \%$ Hydro and $41 \%$ gas. These statistics were published in the Energy Yearbook, 2007 [10].

\section{Pak-China Relation}

Pak-China friendship is inimitable. Pakistan was one of the first countries to recognize the People's Republic of China. As it is quoted "Pak-China friendship is as high as Himalayas". We can exemplify a bit of this close relation in 2008, when both countries signed free trade agreement which helped to enhance the trade relations among the two countries in a faster pace. Diplomatic relation was established in 21 May 1951 between China (Beijing) and Pakistan (Karachi) [11]. Karakoram Highway also called Silk Road, a symbol of great friendship, heading from Northern Pakistan to Western China that is considered to be a wonder as far as mega structures are concerned was mutually constructed by Pakistani and Chinese engineers and opened in 1978. Both countries have trade mostly via this route. China is $2^{\text {nd }}$ largest trade partner of Pakistan having current investment of $\$ 9$ billion and china is developing infrastructure through power plants, roads, and communication nodes in Pakistan.

\section{Evaluation of Minerals Resources Policy and Development}

With constitutional backing, the Federal and Provincial Governments jointly had responsible for the formulation of the first National Mineral Policy in 1995 (NMP-1). The policy was duly implemented by the provinces which also simultaneously provided the appropriate institutional and regulatory framework, while the Federal Government assumed a supervisory role. This policy has since been replaced by the NMP-2, with the same basic institu- tional and management structure as the first. Instead of regurgitating the content of the policies the review and assessment will focus on the main policy directions in the context of their overall aim (Table 2), which is to increase the mineral sector's contribution to the economic development of Pakistan. The main challenges that NMP-1 and 2 seeks to address revolve around the broad themes presented in Table 2 .

Countries that have demonstrated the long-term ability to "manipulate" their mineral resources, not only adding value to them, but substantively integrating the benefits into their socio-economic development are better off than those who have not. The focus of this policy objective is to increase the economic contribution of the sector to Pakistan's economy through, mainly a facilitation of private investments and Joint Venture Partnerships in the mineral sector. The JVP agreement is perhaps one of the most important developments in the global mineral industry today. This alternative policy focus needs more substantive consideration, in particularly as it relates to enhancing the sector's competitiveness and attracting potential local and foreign investment. The only portion of the policy dedicated to this states that "A license/lease may be granted jointly to two or more persons with respect to an area where such an application is made jointly and the liability of the applicants under the license/lease in such a case will be joint and several" (NMP-2).

The formulating of a Joint Venture Agreement for Mineral Exploration can be a tedious legal task, requiring many hours of pother debate to achieve consensus and agreement. This can be especially true within the governance structure of the sector in Pakistan. Many countries now publish investor's guides to mineral exploration to enhance the sector's JVP potentials and thus its competitiveness. These guides are not only to educated potential investors in their mineral industry about the prospects of mining and exploration, but to also ensure that investors align themselves with national development priorities in consideration of their mineral exploration investment plans.

The mineral sector contributes on average $\sim 0.5 \%$ to 
GDP annually, which is likely to increase considerably with the development and commercial exploitation of Saindak \& Reco Diq copper deposits, Duddar Zinc lead, Thar coal and Gemstone deposits. The sectors contribution to economic development is regularly revised down due to the impacts of inclement weather conditions, such as the torrential rains in Sindh Province during August 2011, which compelled the government to revise its GDP growth target [12]. However, GDP data for the mining and or mineral sector are not specific, but are truncated with figures for the production and manufacturing sectors generally. For example, the mining and quarrying sector recorded positive growth of $4.4 \%$ for 2011-2012 against the negative growth of $1.3 \%$ in 2009-2010 [13]. These figures are also included within those for large scale manufacturing which posted a growth of 1.05 percent as compared to growth of 0.98 percent during the first nine months of the fiscal year 2011-2012. With this sort of double accounting, it is difficult to track real actions within the industry. This is also compounded by the fact that the large scale manufacturing industry includes other sector's contribution, such as: pharmaceutical, paper and board, wood product, food beverages and tobacco, nonmetallic mineral products, leather product and textile. This is one major challenge in monitoring target for the industry in order to determine if policy objectives to this end are been met. The World Bank's 2011 Economic Update Report for Pakistan, had no information on the specific mineral industry and failed to mention any mineral (even coal) in its analysis [14]. Since the WB and by extension the IMF are important international partners in the country's economic development, this is a worrying trend.

\section{Competitiveness and Investment}

The competition in the global mineral industry has never been fiercer as it is today. The increasing importance and impact of new players such as; China, India and Brazil and the resurgence of Russia, Australia and Canada, are adding dynamism to all facets of the market. These players are unreserved and relentless to securing their place in the global industry. Pakistan should therefore align itself with best practices of its neighbors (China and India). Moreover, the traditional players and leading in innovation and forging new partnerships with the emerging players. The policy's aim in this regard is to improve Pakistan mineral industry's competitive for scarce and mobile international capital for investment in the sector through a stable and enabling environment. This stable enabling environment is proving a herculean task for the successive governments since NMP-1. Pakistan is depending on foreign aid (World Times, 2011) and is classified as a Lower Middle Income Country by the World
Bank, with debt to GDP ratio of 187.1 as of 2011. Additionally, the country faces significant economic, governance and security challenges to achieve durable development outcomes. The persistence of conflict in the border areas and security challenges throughout the country is a reality that affects all aspects of life in Pakistan and impedes development. A range of governance and business environment indicators suggest that deep improvements in governance are needed to unleash Pakistan's growth potential. The World Bank (2010) ranks Pakistan at 85 with a trade facilitation, as indication of the ease of doing business. The rank represents the country's overall business climate based on seven Indicators. The low to moderate ranking of Pakistan in these two categories hinders its economic growth, compromising potential benefits from its vast mineral resources wealth. The global nature of the mineral industry negates an overly national focus, as is the case with NMP-2. The policy should reflect the global awareness of the national government towards the industry, and its willingness to be flexible with national standards to accommodate global technologies etc.

The World Bank [15] (CFAA, 2003) and GoP has embarked upon an extensive reform program to improve governance, reduce debt, increase public investment, increase revenues, and decrease unwarranted expenditures. Achieving these reforms require: improvements in the effectiveness and productivity of public spending, not only through a better allocation of resources and a more careful choice of policies and priorities but also through better implementation, more efficient delivery of services, and improved controls over financial flows. These reforms are also to be realized at the sectorial levels. Within the mineral sector, the objective is to ensure smooth operational and effective coordination between Federal and Provincial institutions in the implementation of regulatory and legislative regime.

The NMP-2 does not fall short on delineating the portfolio responsibilities of the Federal and Provincial government and their associated agencies (NMP-2). This focus is noteworthy. However, for the industry to find and maintain a niche within the global market the Federal Government must take the lead role through the Ministry of Foreign Affairs (Foreign Affairs Division) and the Ministry of Planning and Development through the Planning and Development Division. Especially, at the international level, investors are more willing to negotiate and dialogue with national (federal) agents than those at the provincial levels. Moreover many of the conflicts at the provincial level, that affect the operations of the sector at that level, for example those within the FATA, GiligitBiltistan, AJK and ICT are constitutionally addressed at the Federal level. These and other constitutional conflicts 
need to be resolved in the interest of better government and management of the sector.

In addition to the federal and provincial government, there are numerous private institutions also involved in the management of the sector. The PMDC, created in 1974 to expand and help mineral development activities, is an autonomous body connected to the Ministry of Petroleum and Natural Resources (MPNR). The Corporation operates four coal mines, four salt mines/quarries and a silica sand quarry producing $\sim 10 \%$ of the coal and $45 \%$ of the total salt production in the country. It's annual turnover during the year 2003-2004 was Rs.584.864 million [16]. NMP-2 shows the government exercising more flexibility and amicability with private companies and investors. This was all part of the aim of securing much needed FDI into the industry along with technical assistance and advances in research and development.

Mineral Investment Facilitation Authorities (MIFAs) are to be established at both level federal and provisional level. At the provisional level it will provide Provincial Mining Concession Rules, while at the federal level MIFA-F will be reconstituted by the MPNR. There will be Mineral Investment Facilitation Board (MIFB) under the MPNR not only context of fiscal policies but also in international contacts with donor agencies and negotiation of mineral agreements to promote the mining sector. Other important concerns under the governance challenge are related to; Regulatory Framework, Fiscal Framework, Legal Framework and Institutions and Research \& Development. The concerns are range from licensing and environmental protection.

Apart from satisfying its local environmental laws, the main objective of NMP-2 is to ensure the exploration for, and development and production of, Pakistan's mineral resources in an environmentally sustainable manner. Pakistan is signatory to fifteen Multilateral Environmental Agreements (MEAs)/conventions/protocols and has ratified all of them. Consequently, it is mandatory for the state to ensure the implementation of the agreements that have been endorsed. The international environmental instruments (conventions/protocols) may be divided into five broad categories: 1) Biodiversity-related Conventions; 2) Atmosphere/Climate Change (UNFCCC); 3) Land Convention/Environmental Cooperation Conventions; 4) Chemicals and Hazardous Wastes Conventions; 5) Regional Seas Conventions and related Agreements.

These legislations should form the basis for establishing environmental standards, for the sector. These should also form an important part of an investor's guide to JVP. The NMP-2 needs to be broadened to include this important consideration, especially if it intends to expand globally and attract international interests and multinational financing from WB and IMF etc. The relevant ministry should make it mandatory for all Licenses for mineral exploration be automatically accompanied by an Environmental Impact Assessment (EIA).

This focus encourages small scale mining and local private participation in the development of the sector. This shows an appreciation of the correlation between mineral exploration and the community development. Other important aspects involve people participation, resources assessment and social and physical infrastructure. Strategies on community based resource development in mineral exploration are some of the most important aspects in preserving the social side of the sector. This is often achieved by the implementation of regular Social Impact Assessment (SIA) study to determine the possible and potential impacts on the community of mineral exploration projects. Too often the economic and financial gains from mineral exploration highlighted and placed at the center of planning and policy making. This is evident in the aim of increasing the sectors contribution to GDP.

There are mounting evidences of large corporations making large profits from mineral exploration projects, yet the communities in which they operate are poverty stricken and suffer from general blightedness. Planners and community development practitioners should be specifically trained to ensure that communities are not disenfranchised from exploration of their resources base. Similarly, they should be equipped with the requisite skills to identify alternative economic bases, when mining operations are discontinued. Communities must be protected against the negative aspect of resource dependency and the resources curse [17].

One very important consideration in the focus local involvement and community development is the issue of minerals and production facilities in indigenous and tribal areas. Many such areas still exists in Pakistan. There must be special consideration to the rights and delicacy of such cultures and customs during pre-mining and postmining operations. At the federal level the Ministry of Minorities through the minorities Affairs Division must assume the lead role in the local involvement within the industry.

\subsection{Mineral Resources and Development of Pakistan}

Pakistan's endowment in mineral wealth, a relatively large labor force of $58.41 \mathrm{million}$ and a mineral/manufacturing industry accounting for approximately $20.1 \%$ of employment, should be a receipt for high growth and socioeconomic development. For this turn around to occur there needs to be significant modification of not only the policy and legislative environment that governs the industry, but also significant changes in the structure of 
management and trade policies for to attract the foreign investment. Pakistan is the sixth most populous country in the world having a large share of "young population" i.e. $63 \%$ below 25 years of age (UNDP 07) Successive failed to moderately successful policies have caused unemployment to mount to $15 \%$.

There is a strong positive correlation between economic growth and natural mineral resources wealth. Neither [18] Dollar nor Kraay (2002), or other recent studies, have investigated whether a country's export structure affects its poverty conditions. If a state's dependence on mineral exports tends to increase its poverty rates, it could help explain why many mineral-rich countries have persistently high poverty rates; it would also inform policy interventions in the sector. If it does not, it would support Dollar and Kraay, and encourage policymakers to focus their efforts elsewhere. Many recent studies imply that mineral wealth, or more specifically, a state's dependence on mineral wealth will hurt the poor. Six different mechanisms could bring this about; four mechanisms are economic and two are political. First, the volatility of minerals prices may hurt the poor, who are normally the first to feel the negative effects of market anomalies. For at least the last century, the international prices for primary commodities have been more volatile than the prices for manufactured goods [19]. Since 1970, this volatility has grown worse [20]. Economies that are more dependent on minerals exports are hence more likely to face economic shocks. Export volatility appears to pose greater problems for the poor, since the poor are less able to guard against negative shocks [21]. Even though debate amongst researches and intellects [22] within the sector wades on, there is no denying that with the correct mixture of legislation, policy, management and efficient implementation and monitoring strategies, this correlation can work in favor of national development.

\subsection{Human Resource Development}

In order to improve the technical and intellectual resource based of the sector, a strong, educated and productive workforce is necessary. The Technical Education \& Vocational Training Authority (TEVTA) is trying to achieve this goal, but there is still a demand for more professionals and engineers in the mining sector. The government needs to make more scholarships and training programs opportunities available. In the short term, the hiring of highly skills foreign professionals is always a viable option for the industry. These should operate alongside local experts as a means of technological transfer for long term sustainability of the sector. Investments should be made to increase the number of facilities for technical education and training and the government should foster collaboration among the local, private and public sectors.

\section{Pak-China Trade Relations}

Pakistan and China are already co-operating closely in the development of Gwadar Port, which would help economic activity in Pakistan and provide an important access route to the sea for China's Western regions, Afghanistan and Central Asian states. A large number of important projects such as the up-gradation of Karakoram Highway, Thar Coal Mining, up-gradation of Pakistan Railways and Power Generation Projects - both nuclear and non-nuclear - are some of the examples of this expanding economic cooperation. Pakistan and China signed a Free Trade Agreement in 2006. The base year for tariff reduction/elimination for China was 2006 and for Pakistan fiscal year of 2006-2007. Pakistan received market access at zero duty on industrial alcohol, cotton fabrics, bed-linen and other home textiles and other goods. China also reduced its tariff by $50 \%$ on knitwear and woven garments. Bilateral trade had reached US\$ 5.79 billion in 2011. The balance is, however, in favor of China. The balance of trade increased from US\$ 2.34 billion in 2007-2008 to US\$ 2.5 billion in 2010-2011. Important factor of trade deficit with China is growing exports of Chinese products to Pakistan including raw materials and capital goods. Since these are more economical, businessmen are inclined to buy more from China. Pakistan, therefore, should be looking at China not simply as an export market, but as a primary source for import of capital goods and industrial raw material. Table 3 shows trade balance between Pakistan and China. It is however encouraging that over the last five years; average rate of growth in exports from Pakistan has been 33\% while average increase in imports from China was $19 \%$. Pakistan and China will enter Phase II of FTA in 2013 when the present FTA will conclude by the end of 2012 [23].

\section{Conclusion and Recommendations}

Conclusively we can say that nature has bestowed Paki-

Table 3. Pak-China Trade (Value: US \$ Million).

\begin{tabular}{cccc}
\hline Year & Exports & Imports & Trade Balance \\
\hline $2005-2006$ & 437 & 1.843 & -1.406 \\
$2006-2007$ & 548 & 2.321 & -1.773 \\
$2007-2008$ & 685 & 3.029 & -2.344 \\
$2008-2009$ & 661 & 2.708 & -2.344 \\
$2009-2010$ & 1.211 & 3.284 & -2.073 \\
$2010-2011$ & 1.645 & 4.145 & -2.500 \\
\hline
\end{tabular}

(Source: Trade Development Authority of Pakistan \& state Bank of Pakistan). 
stan with natural resources in an immense amount so that development in this sector can turn Pakistan's economic instability to developed financial and economic stability. But due to lack of better policies, lack of funds, lack of human resource, lack of machinery, lack of expert this sector is not getting the pace as desired. Pakistani government ought to take some influential and rigid steps to provide a better platform for the international especially Chinese investors, exploration and mining companies regarding oil and gas, minerals, gems etc. Moreover it should provide a space as far as safety and security is concerned so that the international investors and companies can do their job in an appropriate way without any fear. Being a close friend China can do a lot for the development of this sector, so that the interested companies can come to Pakistan for the exploration of mineral resources, which can result into the economic growth of both countries and as a repercussion Pakistan can cope up lots of problem which it is facing, e.g. economic instability, indebted of IMF and World Bank, unemployment, poverty, lack of technical education etc. On the other side Chinese investors and companies can enhance their setup on large scale, their growth and man power. As a moral of story through the development in mineral resources can make Pakistan a progressed and developed country.

\section{Acknowledgements}

I would like to say thanks China Scholarship Council (CSC) funding authority and Prof Huang Delin for his expert and professional supervision. We express gratitude to our families and friends for their unending support. Tayyab Sohail would also like to make special mention of the support of his parents and sisters and brother (Rukhsana, Aysha and Tahir Sohail). I would also want to mention my best Chinese friend Nurbiyam. She always helped me in china.

\section{REFERENCES}

[1] "National Mineral Policy 2 (MPNR-2)," Ministry of Petroleum and Natural Resources Islamabad Pakistan, 2012. http://www.mpnr.gov.pk/gop/index.php?q=aHR0cDovLz E5Mi4xNjguNzAuMTM2L21wbnIvcG9saWNpZXNEZ XRhaWxzLmFzcHg\%3D

[2] "National Mineral Policy 1 (MPNR-1)," Ministry of Petroleum and Natural Resources Islamabad Pakistan, 1995.

[3] "United Nation Development Program (UNDP, 2007, 2008)," Human Development Report, 5 May 2013. http://www.mbendi.com/indy/ming/iron/as/pk/p0005.htm

[4] All Pakistan Commercial Exporter Association, "All Pakistan Commercial Exporters Association of Rough \& Unpolished Precious and Semi Precious Stones," Recog- nized by Ministry of Commerce Government of Pakistan, 2012. http://www.gems.com.pk/index.asp

[5] "Geological Survey of Pakistan (GSP-2003)," Ministry of Petroleum and Natural Resources, 2009.

[6] I. Sodhar, "Pakistan Rich in Natural Resources but Poor in Their Management," World Times Monthely, 1 September 2011.

http://jworldtimes.com/Article/92011_Pakistan_Rich in Natural_Resources_But_Poor_in_their_Management

[7] MBendi Information Service, "Iron Ore Mining in Pakistan," 2012.

http://www.mbendi.com/indy/ming/iron/as/pk/p0005.htm

[8] Khan, et al., "Minerals of Baluchistan Pakistan," 1996.

[9] R. Khan, "Miderals Development in FATA," FATA Research centre (FRC), 2003. http://frc.com.pk/articles/miderals-development-in-fata/

[10] "Pakistan Energy Yearbook," Pakistan Bureau of Statistics Government of Pakistan, 2007.

http://www.pbs.gov.pk/content/pakistan-statistical-year-b ook-2007

[11] "China-Pakistan Relations," China Daily, 14 November 2006.

http://www.chinadaily.com.cn/china/2006-11/14/content 732562.htm

[12] "Pakistan Bureau of Statistics," Government of Pakistan, 2010. http://www.pbs.gov.pk/

[13] "Pakistan Economic Survey (PES-2011-12)," Economic Adviser's Wing, Finance Division, Government of Pakistan, Islamabad, 2011.

[14] World Bank, "Pakistan Economic Update: Poverty Reduction, Economic Management, Finance and Private Sector Development," SAR, 2011.

[15] "CFAA World Report, Country Financial Accountability Assessment Guidelines to Staff," 2003.

http://www1.worldbank.org/publicsector/pe/CFAAGuidel ines.pdf

[16] PMDC: Official Government Website. http://www.pmdc.gov.pk/

[17] B. Shaffer and T. Ziyadov, "Beyond the Resource Curse," University of Pennsylvania Press, Philadelphia, 2012.

[18] D. Dollar and K. Aart, "Growth Is Good for the Poor," Journal of Economic Growth, Vol. 7, 2002, pp. 195-225. doi:10.1023/A:1020139631000

[19] E. R. Grilli and M. C. Yang, "Primary Commodity Prices, Manufactured Goods Prices, and the Terms of Trade of Developing Countries: What the Long Run Shows," The World Bank Economic Review, Vol. 2, No. 1, 1988, pp. 1-47. doi:10.1093/wber/2.1.1

[20] C. Reinhart and P. Wickham, "Commodity Prices: Cyclical Weakness or Secular Decline?” IMF Staff Papers 41, 2 June 1994, pp. 175-213.

[21] S. Sinha and M. Lipton, "Damaging Fluctuations, Risk, and Poverty: A Review, Background Paper for the World Development Report 2000/2001," 1999.

[22] S. Hussain, "Natural Resource Abundance and Economic Growth in Pakistan," Euro Journals, No. 15, 2009. 
http://www.eurojournals.com/EJEFAS.htm

[23] N. A. Memon, "Pak China Trade Relations," Pakistan Textile Journal, 2012.
http://www.ptj.com.pk/Web-2012/08-2012/Chinese-Revi ew-Dr-Noor.html 